a sterile, water ; sterilization may be necessary if the water is used in a hospital, and for process water in food industries further treatment may be desirable to improve the keeping qualities of the product. Among the most promising recent developments in methods of examining water are membrane filtration, and the use of synthetic media containing only pure inorganic substances. Dr. Windle Taylor urgedand this was strongly supported in discussion of his paper-that standard bacteriological methods should be used in examining water supplies. Several members also referred to the urgent need for a second edition of "Methods of Chemical Analysis as applied to Sewage and Sewage Effluents", the first edition of which was published by the Ministry of Health as long ago as 1929.

The discussion-a very brisk one-which followed the papers covered a wide range. Opinion seemed to be general that there is a need for a standard method of determining the toxicity of industrial effluents to fish ; an attempt is in fact now being made to develop such a method, and the Ministry of Agriculture and Fisheries has announced that it proposes to set up a laboratory in London in which samples submitted will be tested. Several speakers referred to the inadequacy of the widely used test for biochemical oxygen demand of effluents, and it is clear that much further work is required to determine rates of oxidation of pollutants, both under laboratory conditions and in different types of rivers. Only when this information is available will it be possible to predict with confidence the effect of an effluent on the level of oxygenation of a river-a very important matter to a river board proposing to frame by-laws regulating the quality of effluents in its district.

\section{RESEARCH ADMINISTRATION CONFERENCE}

$\mathrm{T}$

HE eighth annual conference on "The Administration of Research" brought together nearly three hundred leaders of industrial, university and government research laboratories at New York University during September 8-10, coinciding with the opening of the centennial celebration of the College of Engineering of that University. The Conference is arranged each year by an informally organized group, mainly administrators of research and development in the physical sciences. Attendance is by invitation and proceedings are published by the host university. The programme for 1954 was designed for discussing specific incidents pertaining to management of the 4,000 million dollar research and development business throughout the United States.

At each half-day symposium a series of four or five brief presentations was followed by lively discussion. The first symposium, "Appraising and Rewarding the Researcher's Output", was opened by Dr. Exic A. Walker, dean of engineering at Pennsylvania State College, where the Conference was founded in 1947. Observing that "we have passed through the stage of random creativeness and entered an age of deliberate creativity", Dr. Walker said it is up to the research man to sketch the course the engineer will follow toward the prophesied increase of 100,000-150,000 million dollars in the gross product of the United States by 1960. Although no objective measure of an individual scientist's productivity has yet been found, the fact that empirical evaluations are becoming more prevalent and systematic was brought out by each speaker.

Mr. Edwin A. Speakman, general manager, Guided Missiles Division, Fairchild Engine and Airplane Corporation, described the semi-annual rating plan of his company. He noted that supervisors and administrators must often evaluate and reward a researcher's potential far in advance, as it may take several years for his efforts to materialize. Dr. Clyde E. Williams, director of the Battelle Memorial Institute, emphasized that scientific integrity, selflessness and ability to work in a team are considered most important for promotion. The National Bureau of Standards, according to its director, Dr. A. V. Astin, favours appraisal and promotion of staff members through the collective judgment of committees at various levels. Although it is possible to promote a scientist to the highest grade without assigning him executive responsibility, such assignments are difficult to avoid, and Dr. Astin suggested that this situation warrants further study.

The Conference speaker from outside the United States was Dr. John J. Green, of the Defence Research Board of Canada, who is science advisor to the Royal Canadian Air Force. He summarized, with individual examples, awards which are available for merit in research; these include sabbatical years, cash awards, royalties from inventions, the Queen's honours lists, and the annual gold medal of the Professional Institute of the Civil Service of Canada.

After a luncheon, addressed by Henry T. Heald, chancellor of New York University, the second symposium dealt with a number of general aspects of "Management in the Research Laboratory". The chairman, Dr. James B. Austin, vice-president of the Research Division, United States Steel, gave some pointers on the "Control of Service Groups". $\mathrm{He}$ emphasized the concept of service to the research staff, pointing out that machine-shop backlog must be small enough to accommodate rush-work for scientists. Informal contacts by the scientist with the service technician are encouraged and priority determinations in shops work, for example, are made through weekly conferences. In exploring "The Use of Work Simplification in a Research Laboratory", Mr. Allan H. Mogensen, management consultant, gave examples of how other organizations have been helped by such a programme. He urged that all workers be taught to keep asking 'why', and recommended direct communication, rather than suggestion boxes, as the channel for ideas.

The delicate problem of "Inter-Departmental Relations of Research to Production and Sales" was treated by Mr. Kenneth H. Klipstein, general manager of the Research Division, American Cyanamid Co. Not only individuals but also whole sections of an organization must practise team-work in to-day's industry and government. To have the research director as a part of top management and to use co-ordinating committees for active planning and review are approaches $\mathrm{Mr}$. Klipstein has found most effective. Similar experience was described by Dr. Blaine B. Wescott, executive vice-president, Gulf Research and Development Co. Having research consolidated in one department rather than dispersed among operating departments, he agrees, has more advantages than disadvantages. Qualifications of an engineering manager were discussed by $\mathrm{Mr}$. Howard L. Richardson, vice-president of engineering oper- 
ations, Sylvania Electric Products, Inc. No stereotyped combination of traits has been found, he pointed out. A technical background is invaluable, but it does not teach such executive arts, as how to sell ideas and how to make decisions based on judgment where facts are sparse.

In the third symposium, "Communication Problems in a Research Operation" were illustrated, The chairman of the session, Dr. Paul R. Beall, consultant to the Deputy Chief of Staff, Development, U.S. Air Force, was also chairman of the Conference Programme Committee. Alluding to the disappointment a company may experience when inadequate communication of a design proposal makes it lose a large contract, Dr. Beall gave some tips, including a dramatized presentation on how to make an effective oral presentation. "How ASTIA Can Help Your Research" was indicated in a series of specific cases by Mr. Leslie E. Neville, director of the Armed Services Technical Information Agency (ASTIA) This Agency is a clearing-house available to the U.S. Defense Department and its prime contractors. A single report, for example, obviated a long-range study of corrosion which saved one company fifty thousand dollars and two years in time.

Dr. Howard G. Vesper, vice-president of the Standard Oil Co. of California, asserted that good external communication with its clientele is at the heart of effective service by a research laboratory. He agreed with the thinking of Dr. Wescott and Mr. Klipstein as regards a separate laboratory organization and its co-ordination through committees. At California Research, Inc., a conscious attempt is made to bring group leaders and even bench workers into study-group discussions, and also to permit them to see their 'brain children' put on the production line. A very specific tool of communication is "The Director's Mimeographed Weekly Bulletin", described by Dr. Helmut E. Landsberg, chief of the Climatological Services Division, U.S. Weather Bureau. It helps to bridge the gap resulting from bigness.

The special problems of "Communication in Classified Research", brought up again and again during the Conference, were given more extensive treatment by one in a position to know, Dr. Norris E. Bradbury, director of the Los Alamos Scientific Laboratory of the Atomic Energy Commission. The solution of internal communication problems, he said, is really a function of how the director and the people with whom he works feel toward one another. No tools or procedures can compare with 'attitudes' when it comes to communication. The 'need to know' is interpreted broadly within Los Alamos, and free discussion among staff develops bright ideas in the most unexpected places. In external communication, security restrictions cause difficulties that Dr. Bradbury does not know how to overcome. $\mathrm{H}_{\theta}$ believes there can be more common sense in the sharing of scientific information without endangering national security.

The fourth symposium, on "Physical Facilities for Research", included contributions from Mr. Walter $\mathrm{H}$. Verdier on the planning and construction of the new Applied Physics Laboratory of Johns Hopkins University; from Mr. A. R. Johnson, of Arthur D. Little, Inc., on the building of adequate laboratory structures for less than 12 dollars per sq. ft. ; from the architect, Mr. Ralph Walker, who spoke from wide experience on "Designing Buildings for Research" ; and from Dr. Clifford F. Rassweiller, vice-president for research and development, Johns
Manville Corporation, on "Building for Greater Research Productivity". All agreed that the building is merely a tool for productive research. There were some differences of opinion about the size of the 'modular design' and about how easily transferable the partitions should be. Dr. Rassweiller particularly emphasized thinking in terms of things that will inorease research productivity. We should not just ask "How much can wo save in building ?", he declared, but "How can we build a facility that will give greatest returns on the dollars invosted ?".

The final symposium, on "Basic Research in an Applied Research Laboratory", elicited stimulating discussion to the very end of the Conference. The chairman of the session, Mr. Earl P. Stevenson, president of Arthur D. Little, Inc., had served this year as general chairman of the Conference Advisory Committee. He strongly favoured the mixing of some basic research along with applied, and explained how his company established the 'office of science director' with no administrative responsibility but with a broad mandate for providing scientific leadership through the informal organization. Dr. Maurice Nelles, director of the Borg-Warner Central Research Laboratory, gave a concrete example of how basic results grew out of applied research on sheet metal work. "We used to be asked", he said, "what have you discovered that is new? Now we are asked, when will you complete that project?" This signifies, Dr. Nelles concluded, that science may have reached the end of progress by analysis and separation-that random hunting has passed its prime-and we must plan deliberate creation and synthesis. "CortisoneA Product of Joint Academic and Industrial Basic Research" was the title of a vivid description by Dr. Randolph Major, vice-president of Merck and Co., Inc. Without close team-work between applied and basic approaches, the hormone synthesis which resulted in this drug could never have been possible.

Dr. Ralph Bown, vice-president of the Bell Telephone Laboratories, suggested that "Research is simply an effort to understand more about things". The way for an applied laboratory to get a balance which includes some basic research is to employ people who are concerned in understanding the things which interest the company and then to keep them informed of those interests. Bell Laboratories, Dr. Bown said, relies less on committees and more on delegation and co-ordination through the line than seems to be true of some others. When a man has a bright idea, the general policy is that he should pursue it, if it is reasonably applicable to the company's work; as soon as it reaches the stage where it is not, he should publish interim results so that someone else can continue the research.

Mr. Alex Stewart, director of research of the National Lead Co., spoke on "Gold is where you find It", in people as well as in minerals. His company sponsors exploratory and basic research in universities and, when timely, transfers it to the company laboratory. Also, the National Lead Co. has the unique practice of making a research and development team actually demonstrate the salability of a proposed product before it is turned over to the Sales Department.

At the dinner meeting, Major General William M. Creasy, of the Army Chemical Corps, spoke candidly of needs and proposals for strengthening the research and development work as well as general operations of his Corps. $\mathrm{He}$ is setting up an advisory committe 
and has engaged a leading industrial scientist to direct all scientific operations.

Attendance at the Conference was reported to be a little more than half from industry and the remainder divided equally between government and universities. The 1955 Conference will be held at Northwestern University, Evanston, Illinois. Dr. Thomas H. Vaughn, vice-president for research and development of the Colgate-Palmolive Company, is the new chairman of the Advisory Committee, and Dr. Maurice Nelles the new chairman of the Programme Committee.

\section{A. V. Astin}

IVAN AsAY

\section{INDIAN ASSOCIATION FOR THE CULTIVATION OF SCIENCE}

\section{REPORT FOR THE YEAR 1953-54}

$\mathrm{T}$

HE annual report for 1953-54 of the Indian Association for the Cultivation of Science has recently been published in full*, and although reference has already been made in these columns to the Association's activities during the year (Nature, September 11, p. 495) when the acting director, Prof. P. Ray, originally presented the report at the annual general meeting of the Association, held on July 30, a fuller résumé that is now possible, from the published report, is not without interest. Besides the usual appended financial statements and lists of books acquired during the year and serials received on an exchange basis, the account includes, among the departmental reports of research, departmental lists of papers published during the year. Details are given of the five-year plan of development covering the financial years $1954-59$, which was prepared at the request of the Finance Committee and the Government of India and finally approved by the Council on March 29, 1954. The plan contemplates non-recurrent grants totalling Rs. $1,138,200$ for equipment and Rs. 1,771,393 for land and buildings, of which two-thirds is to be provided by the Government of India and one-third by the Government of West Bengal. Recurrent grants, which are estimated to increase from Rs. 465,630 in $1954-55$ to Rs. 777,415 in 1958-59, and to total Rs. $3,237,592$ in the quinquennium, will be provided mainly by the Government of India as at present. The Plan does not involve the establishment of any new Department.

In the Department of General Physies, X-Rays and Magnetism, investigations on the transport properties of matter have been started. Results obtained for the conductivity of argon-neon mixtures using Kannuluik's thick-wire method agree with the $12: 6$ power model of the intermolecular potential but not with the inverse power model. B. N. Srivastava has applied the theory of the thermodynamics of irreversible processes in investigating the thermal effusion of substances capable of existing in two isomeric forms. The unit-cell dimensions of fluoranthrene and phthalic acid have been determined from morphological and X-ray studies, and the dimensions of the intermicellar zones of some fibres have been obtained by incrustation of metals like gold and silver in the colloidal form in the fibre framework. The investigation of low-angle $\mathrm{X}$-ray

* Indian Association for the Cultivation of Science. Annual Report for 1953-54. Pp. 64. (From the Association, Jadavpur, Calcutta, 1954.) scattering continued as well as X-ray studies of redcoloured silver glass and of the nature of adherent metal films of glass surfaces. Determinations of the magnetic anisotropy of paramagnetic crystals of the elements of the iron group continued, and a new, simple and efficient electrodynamic method of measuring magnetic fields, with an accuracy of about 5 parts in 10,000, has been developed. Experimental and theoretical studies on the electrical, thermal and magnetic properties of graphite crystals also continued.

In the Department of Optics, the ultra-violet absorption spectra of phenetole, $n$-butyl benzoate, $\alpha$-chloronaphthalene and $\alpha$-bromonaphthalene have been determined in the liquid and solid states at low temperatures and also those of $o_{-}, m$ - and $p$-toluidine, while the Raman spectra of $o$ - and $p$-chlorotoluene in the solid state at $-180^{\circ} \mathrm{C}$. have been compared with those for the liquid state. Studies of the Raman spectra of $1: 2$-dichloroethane and $1: 1: 2$-trichloroethane in the vapour state indicate a marked change in the ratio of the number of the two types of molecule with the change from liquid to vapour state, attributed to the influence of the strong inter-molecular field in the Iiquid state. The absorption of radio waves of frequencies in the range $250-920 \mathrm{Mc} . / \mathrm{s}$. in benzyl alcohol, benzyl chloride and benzylamine at different temperatures has also been studied, as well as the absorption of $3 \cdot 3-\mathrm{cm}$. microwaves in chloroform and ethylene dichloride. The number of events in which a neutral particle in cosmic rays produced in a lead absorber either one charged meson or more neutral ones moving along different paths was determined.

In the Department of Theoretical Physics the equivalence of the Born approximation to the covariant perturbation theory has been demonstrated by considering the scattering of fast electrons by the Coulomb field of the atomic nuclei, and the method of Brinkman and Kramers has been extended to the capture of the electron in arbitrary excited orbits. Theories of the nuclear shell structure model and Bohr's liquid-drop model are being studied with the view of finding common ground for the two approaches.

In the Department of Physical Chemistry, investigations on the chain transfer of vinyl acetate using hydrocarbons, alcohols, ketones and chlorinated solvents gave results in agreement with the $\alpha$-hydrogen theory. With acrylonitrile the results also agree with that theory except when halogenated solvents are used. A study of the kinetics and chain-transfer coefficients of vinyl and other monomers in the hydrogen peroxide-catalysed systems has led to a method for evaluating solvent transfer in the catalysed system. Work with nine azonitriles as initiators in the polymerization of vinyl monomers was completed, and work on the synthesis of hydroperoxides and the $\mathrm{X}$-ray-initiated polymerization of vinyl monomers commenced. Lauroyl, caprinyl and caproyl esters of methylethylcellulose have been prepared. Seven osmometers have been constructed and calibrated for the determination of the molecular weight of co-polymers. Results obtained for the molecular weight distribution of polystyrene were in good agreement with the theoretical distribution equation of high polymers deduced by $\mathrm{S}$. R. Palit and K. C. Majumdar. The solubility of anthracene and phenanthrene in the binary systems ethyl iodide or iodobenzene, cyclohexane or cyclohexene, has been determined. 